\title{
Child Education in Families in the Age of Technology Information and Communication
}

\author{
Wirdatul Aini ${ }^{1 *}$ \\ ${ }^{1}$ Department of Non Formal Education, Faculty of Education, Universitas Negeri Padang, Padang, Indonesia \\ *Email: wirdatulaini@fip.unp.ac.id
}

\begin{abstract}
Today the development and progress in the field of science and technology (Science and Technology) are growing rapidly. Thanks to the development of advances in science and technology, humans can create tools and equipment that are more modern and great for various activities, so that in daily activities various facilities are available that enables humans to be helped to achieve goals. On one side of the progress in the field of science and technology has a positive impact, including can help humans to make communication and interaction quickly with others; can gain knowledge and experience through mass media, etc. Besides the positive impacts of science and technology that are currently developing, not a few negative impacts arising from the progress of science and technology. The development of science and technology that occurs in society will affect the education of children in the family. Parents as the first and foremost educators in the family should have tips and strategies to educate children in the era of information and communication technology. The purpose of writing this article illustrates educating children in families in the era of technology and information. The method used in writing this article is the study of literature and the experience of educating children in the family in the era of information and communication technology. Educating children in the era of information technology or the digital age the family must strengthen character education in children, always controlling the communication tools used by children such as the use of gaged in various programs such as facebook, media line, twitter, and other sites on Google
\end{abstract}

Keywords: education of children, families, science and technology era

\section{INTRODUCTION}

Progress in the field of technology and information is now growing very rapidly. Almost all human life has been influenced and entered by information and communication technology, including in the world of education. Advances in technology and communication from one side have positive and constructive impacts on human survival. In this case, advances in technology and information help in all activities to meet the various needs of human life. Knowledge and information needed by humans at this time are very easy to find through the internet/web. Nowadays, also known as globalization, or a world without limits, everything we can get in a moment, and close. What is happening in that part of the world, now we can enjoy it and find out immediately, all we have to do is select the channel through the television media at home, and there is no need to search out there. Besides the positive impacts of technological development and communication, not a few negative and destructive impacts (damage) that occur if humans do not have a critical and selective attitude.

Current developments in technology and information especially related to the use of digital devices have influenced various children's lives [1]. It can be observed that currently, children are very creative, actively using digital technology in various fields. Today's children are known as the native digital generation, meaning they have known digital media since birth, so they are not awkward, and are very agile using digital devices [2]. Among the characteristics of children living in the digital age is that their dependence on digital technology is very high. Today's children are spent using digital technology, in any situation children are preoccupied with gated, and they generally do not care about the environment, with family, neighbors and so on. The behavior of using digital technology directly or indirectly influences the formation of children's character.

The main characteristics of children in the digital age are connected, creative, and confidence [3]. Connected is this generation said to be a person who is good at socializing with his community, a generation who is good at interacting on social media, such as facebooks, line media, twitters, etc. Then it is said that this generation is creative, this generation is rich with ideas, brilliant ideas and able to communicate with others. Among the younger generation, they are creating through social media in terms of the startup and other industries driven by young people when there is now trade via the internet/web. Furthermore, the digital generation is known as the characteristic of confidence, characterized by the characteristics of this 
generation of people who are confident, able to debate in public express ideas and dare to debate in public.

Digital generation if examined has characteristics from the aspects of identity, privacy, freedom of expression and learning process [2]. Identity is that this generation is busy making identities in the mass media, through Twitter accounts, Instagram facebooks, etc. This shows they are introducing themselves to the world that they are open to getting to know each other wider. Then the privacy aspect of this generation tends to be more open to the outside world, to think aggressively, ie to act and act without thinking more mature and clear. While in the aspect of freedom in expression, the digital generation is free to express themselves, do not want to be regulated and dictated by others. Freedom of expression is also characterized by control of the internet for expression. Then from the aspect of the learning process marked by the characteristics of learning trends, searching for knowledge, information or skills using Google access, Yahoo or other search engines. The ability to learn this generation is partly faster because they find information faster, and some of this generation is sometimes complacent and affected by negative sites, even many of those who fail to achieve their learning goals.

Based on an explanation of the characteristics of attitudes, children's behavior in the 4.0 revolution era which is characterized by the increasingly strong use of digital media, parents should be able to develop parenting to produce a generation that is not easily affected by the negative impacts of the digital era. Digital media should be used for positive and beneficial purposes. The pattern of education in the family as what can be applied by parents to educate children at home, so that if the children are adults they have a selective attitude, critical of the progress that occurs in the digital age. The role of parents is to prepare children for success and success in the age they face. As first and foremost educators, it is highly expected to be able to educate children to be selective towards the development of digital media that is developing at this time. The role of parents in the effort to develop character values, through the cultivation of moral values, religious learning needs to be strengthened in children in the digital age. The moral values contained in the Pancasila points become an important part that needs to be internalized in the daily lives of children in digital.

\section{DISCUSSION}

Based on the problems found, children who live in the digital era/millennium era are very susceptible to being affected by digital media from the aspect of the negative impact it causes. Among the more aggressive children, want freedom in doing whatever they want. Moral depravity that occurs increasingly shows a fairly increasing scale, both moral depravity that is small, such as opening genitals, bikini contests for teenagers with a riot between the opposite sex and large-scale depravity such as narcotics and drug abuse. A report from the Indonesian Central Statistics Agency (BPS) noted increase in crimes from 2010-2012 alone increased by around $17.2 \%$, especially criminality on motorcycle theft. Many more problems of adolescents in the digital era include free promiscuity between young men and women especially in big cities, among the causes, is the influence of the mass media, using digital media, without any control especially from parents, because most of the time the child is in the family and the community.

To overcome the problems of children in this digital age, character education in the past few decades has become a part of the Ministry of Education and Culture's strategic program. According to the National Education 2015, the meaning of character in the language is personality, mental characteristics. As for the character or personality can be developed through innate factors and exogenous factors such as the natural surroundings, education and external factors in general. Meanwhile, according to Wynne, characters come from the Greek to mark (mark) and focus on how to apply the virtue values in the form of actions or behavior. In the religious approach, according to some experts, there is no fundamental difference between morals or character. Both can be said to be the same, although no doubt some experts disagree with equating the two terms. The statement was strengthened by Al Habsyi[4], the notion of morality is more accurately referred to manners, the science that seeks to recognize human behavior, then give a mark to good or bad attitudes under the norm. Thus, it can be understood that character is the value of a person's behavior whose scope does not only concern about relationships with fellow human beings but also relationship with God and environment which are presented through thoughts, attitudes, feelings, words and actions based on religious norms, karmic laws, culture, and customs.

From the definition of character above, the concept of character education was born as stated by several experts including Megawangi[5], which defines character education as an effort to educate children to make wise decisions and practice it in everyday life, so they can provide a positive contribution to the environment. Meanwhile, another understanding was also stated by William[6] that character education as a combination of attributes, patterns, attitudes, behaviors that are integrated to lift one's identity and distinguish each individual from other individuals. Education character according to Lickona[7], has three main elements, namely knowing the good, loving the good, and doing the good.

Megawangi[5] offered the idea of developing a characterbased holistic education model which is known as the planting of nine pillars consisting of: First, the love of God and the universe and its contents. Second, responsibility, discipline, and independence. Third, honesty. Fourth, respect and courtesy. Fifth, love, care and cooperation. Sixth, confident, creative, hard work, and never give up. Seventh, justice and leadership. Eighth, kind, and humble. Ninth, tolerance, love of peace and unity.

Character education needs to be applied to children in this digital age, among the most important family roles to shape the child's character. The family is the base for the formation and development of character. The formation of 
a person's character is essentially influenced by innate factors (fitah-nature) and the environment (including education). The influence of nature/environment factors can be understood that every child born in essence has a good character. However, this potential must be fostered through socialization, interaction, and education that was first obtained from the family environment. Therefore, the family plays a vital role in the formation and development of the character for each of its members. This was confirmed by Megawangi cited by Latifah[6], children will grow into personal characters so that the nature of every child born holy can develop optimally. Thus, character education with the role of the family has a close and binding relationship. The family is the first and foremost education for the character education of their children. If the family fails to do character education for their children, it will be hard for the community to participate in improving it. Failure of the family in the implementation of character education results in the growth of people who do not have character. Therefore, every family ideally has an awareness that the character of society and the nation is determined by the implementation of character education in the family.

Character education in the family is essentially a necessity. It is undeniable that the family is the first educational base in every human life. Moreover, formal education in general as stated by Nata[5] has now faced a crisis of character education caused by several things including: first, the world of education has forgotten its main goal of developing knowledge, attitudes, and skills simultaneously and in balance. Our education world has provided a very large portion of knowledge, but forgetting the development of attitudes/values and behavior in learning. Second, the education system in Indonesia is limited to preparing students to enter the tertiary level or only for those who have talent on the academic potential of high intelligence alone. Third, the world of education in Indonesia is currently stuck on preparing impromptu humans or instant humans. The current four educational practices are dominated by the ideology of capitalist economies, and liberalism which is characterized by, among others, the emphasis of the curriculum in the field of science, technology and skills meeting the needs of the business and industry world, regarding education as a commodity being traded.

Based on some of the causes above it can be said that formal education both in general and Islamic educational institutions are still far in touching the scope of character. Moreover, our children currently live in a digital/millennial era that has a negative impact, including being easily influenced by behaviors that damage moral. Therefore it's time for the family to become the first character education development institution for its members. It can be stated that when character education is felt to be weak and unrealized at the level of formal education, the family automatically provides the basis for full character education, a reality that fortifies every child from the fluctuations of lust that tempt him. According to Sukiyani \& Zamroni[8], the purpose of character education in the family are to provides good morals to every child to be able to behave by applicable rules and ethical norms. Besides, through character education in a family is the child will have a comprehensive understanding to become a scientist with character as well as a polite and intelligent, tolerant, dynamic, advance in science, and technology-based on faith and devotion to God Almighty.

The family as the first educational base for its members (children) plays an important role in creating a calm and quality psychological and cognitive condition. It is best if the family is stated to have a large role in personal development (personal growth). These are the development of intellectuality which is oriented towards achievement, morals, independence, and productivity with the intention that each person in the family can solve problems appropriately, be able to be self-sufficient, competitive, adaptive and can advance their social and cultural environment, and behave ethically.

Furthermore, life in the family besides functioning as a place for personal development is also the smallest social network. Each family should ideally play a role in enhancing relationships to develop social networks between family members and create harmonious communication and relationships. Furthermore, the role of the family is at the same time organizing, controlling and maintaining the survival of the family to unite each individual in the form of a family.

According to Helmawati[9], explains the function of the family in the socio-cultural context in Indonesia into five elements, namely: first, the family functions as a primary alliance, the relationship between family members is fundamental and exclusive because of biological ties, legal ties and the presence of togetherness in sustaining life. Second, as a giver of affection on the base of biological ties or legal ties that are driven by a sense of duty and responsibility.

Third, as an institution of formation caused by role models, religious beliefs, cultural values, moral values, both sourced from within the family and from outside.

Fourth, as an institution to fulfill needs, both material and mental and spiritual. Fifth as an institution of participation from community groups, namely interacting in various activities, both with other families, the community at large and with the surrounding natural environment. Thus the family is essentially responsible and determinant in the formation of good human beings, through a simple educational process and carried out applicative in everyday life.

Likewise, some expert opinions suggest that the personality and intellectual development of children in the first two years are determined by family factors. If the family does not pay attention to this period then the personality and intellectual development of the child certainly go wrong. Koning, as quoted by Hufad in [4], asserts that the foundations of character and personality are formed in the initial development from the age of one to four years in the smallest environment, the family. Based on that education in the family becomes something that cannot be missed, because in the family every child gets the basics of education and knowledge, practical 
knowledge. Without quality family education, it is not possible to be born of quality human beings as well. Parental involvement shapes the child's personality in the era of the development of science and technology. This aims to prevent deviant behavior that is not following moral norms and moral values in the child. Thus parenting, guidance parents means a process of interaction between parents and children which includes activities such as nurturing, educating, guiding, and disciplining in achieving the process of maturity both directly and indirectly.

In terms of functions, each family has a variety of functions, both economically, socially, education, protection, love, reproduction, and other functions. Economic function means the family becomes the backbone of obtaining and managing economic activities professionally. The family will be strong if economic terms are sufficient. Family welfare has a significant contribution in creating wholeness, harmony, continuity and family happiness. In the family, there must be a process of economic empowerment that can involve all members proportionally. This function is carried out by finding sources of income to meet family needs, regulating the use of family income to meet family needs, and saving to meet family needs in the future.

The social function is the family according to Rahmat[10], is the first means in the process of social interaction and establishing close relationships within one family or broadly. This social function can also be interpreted that the family is the first source of inspiration in establishing communication through the process of speaking politely and appropriately. The family is the first place where all members get an understanding and inculcation of sociocultural values that exist in the community. Life attitudes, values, ethics, manners, character which are the property of the community, are obtained and instilled early on in family life. A child from the family knows and understands the norms that are good in society, knows how to socialize with fellow humans, respect nature, and social life. Children as the next generation of a family get a basic education in the family about the behavior following the phase of development.

The family as an educational function, which the family must be a place for all members to socialize with each other, communicate and interact healthily and productively. The family also became the first place to provide education for all children. In family life, the educational process runs very effectively because the interactions that occur are very intensive. The family as the first place of education for children of the next generation. An ideal family must be a place where educative interactions occur. Parents provide education to children according to the age level of the child. This educational function can be applied by sending their children to school according to age development. Education in schools aims to have children have the knowledge, skills, and development of behavior that is following their talents, interests.

Family as a function of love. The family must be a place to grow and sow love and affection among all its members. If children get an atmosphere of love and affection in the family, then the children will grow into a person full of love and affection. This will be a great asset for all family members to develop an attitude of love and affection in wider life. In one family, it is hoped that each will give attention and affection. With an abundance of affection, it is hoped that human beings who have good emotional intelligence will be formed to create a quality family, and so on will be formed qualified generations, so that it will create a comfortable atmosphere in social life.

Furthermore, the family as a function of protection. According to [10], the family must be a safe, comfortable and placating place for all its members, because of the atmosphere of mutual protection. All family members feel calm, safe and peaceful because they feel protected. There are no acts of discrimination, violence, coercion, which makes any family member feel threatened and insecure. The family becomes a place that provides comfortable protection for its members. Protect each member from actions that are not good, so that family members feel comfortable and protected from things that are not pleasant.

Then the family as a function of reproduction. The family is the only legal and legal means for developing offspring. Families form children as the next generation of the nation and state. The purpose of family life is to get offspring. This cannot be obtained legally and lawfully, if not through marriage and family formation. This function is the most intrinsic in a family because it has to obtain legitimate offspring, which is expected to be of highquality descent. Parents carry out this function by going through a process where a mother is pregnant, giving birth, raising, caring for and caring for children until a child reaches adulthood and is independent in his life.

\section{CONCLUSION}

Based on the description that has been stated, that children in the era of technology and information are characterized as individuals who are quick to get along, creative person, and a person who is confident in every activity undertaken. The era of technology and information has a positive impact on the development of children's knowledge, skills. Children easily find a variety of knowledge, and skills through mass media through the Google network, Yahoo Internet, Twitter, Facebook, etc. However, information technology harms children and their lives, various negative actions taken by children, such as promiscuity, using drugs, the occurrence of acts of violence in the family and community. To overcome the negative problems that occur in children in the digital age, the role of education in the family, especially parents as first and foremost educators is very important, especially in the formation of character. Character development is intended as the formation of character, good personality by instilling the values of God's love and the universe, responsibility, discipline, independence, honesty, respect, courtesy, compassion, creative, hard work, never give up, etc. 
Era Digital, 1st ed. Jakarta: Kemendikbud, 2016.

Then parents in the family also function as educators to educate children towards good direction, economic functions in terms of meeting the needs of family members, religious functions to instill religious teachings, social functions for the development of the socialization of children in the family and society, protection functions to produce comfort for family members, as well as reproductive functions, namely to produce offspring carried out through legal marriage.

Parental care for children in the digital era / the development of information technology will have a positive impact on the dimensions of character formation and personality of children. Parents must show great responsibility in guiding, and guiding children in using digital devices and media. Parents must control the child in the use of digital media devices. Communicating behavior internally parents with children as a determinant to protect children from the negative effects of digital media. The victory and success of a child in the education process at a later stage are precisely determined by the educational process within the family, besides education at school and in the community

\section{REFERENCES}

[1] Herimanto and Winarno, Ilmu Sosial Dan Budaya Dasar, 5th ed. Jakarta: PT Bumi Aksara, 2012.

[2] Kemendikbud, Seri Orang Tua Mendidik Anak di
[3] B. Bumbungan and B. Ciba, Menumbuhkan Karakter Siswa Berbasiskan Budaya Lokal Tabe' di Era Digital. 2018.

[4] Zubaedi, Desain Pendidikan Karakter; Konsepsi dan Aplikasinya dalam Lembaga Pendidikan. Jakarta: Kencana, 2012.

[5] R. Megawangi, Pendidikan Karakter: Solusi yang Tepat untuk Membangun Bangsa. Bogor: Herritage Foundation, 2004.

[6] S. Aziz, Pendidikan Keluarga Konsep dan Strategi. Yokyakarta: Gava Media Title, 2015.

[7] A. Sudrajat, "Mengapa Pendidikan Karakter?," J. Pendidik. Karakter, vol. 1, no. 1, pp. 47-58, 2011.

[8] F. Sukiyani and Zamroni, "Pendidikan Karakter dalam Lingkungan Keluarga,” J. Ilmu-ilmu Sos., vol. 11, no. $1,2014$.

[9] Helmawati, Teoritis Pendidikan Keluarga Praktis. Bandung: Remaja Rosdakarya, 2014.

[10] S. T. Rahmat, "Pola Asuh yang Efektif untuk Mendidik di Era Digital," J. Pendidik. dan Kebud. Missio, vol. 10, no. 2, pp. 143-161, 2018. 